Nig. J. Biotech. Vol. 37(2): 32-46 (Dec. 2020)

ISSN: 01891731

Available online at

http://www.ajol.info/index.php/njb/index

and www.biotechsocietynigeria.org

DOI: https://dx.doi.org/10.4314/njb.v37i2.4

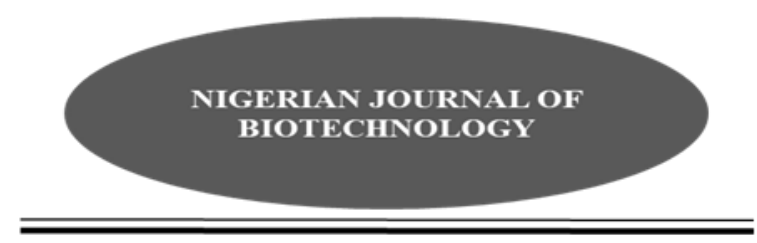

\title{
Nutritional properties of indigenous fermented condiment (ogiri) produced from partial substitution of castor oil bean (Ricinus communis) with soybean (Glycine max) seeds
}

\author{
*Okwunodulu,I. N., Onwuzuruike, U. A. and Agha, E. F. \\ Department of Food Science and Technology, College of Applied Food Sciences and Tourism, Michael \\ Okpara University of Agriculture, Umudike, Abia State, Nigeria.
}

\begin{abstract}
Recently, in Nigeria, there has been a series of controversial publications and debates over the use of seasoning cubes and monosodium glutamate as cancer inducing agents. With this, the use of local condiments like Ogiri has become an option. Ogiri is traditionally produced from castor oil beans which is scarce in some communities. This study therefore explored the possibility of substituting castor oil bean with soybean to obtain an acceptable Ogiri. Proximate, mineral and vitamin composition and sensory characteristics of the substituted Ogiri samples produced were evaluated using standard methods. With increase in soybean substitution levels, proximate analysis showed an increase in crude protein (17.33\%-31.68\%), crude fibre (0.47-1.71\%) and fat (13.76-20.23\%) contents while ash (3.63-3.21\%) and carbohydrate (48.13\%-23.55\%) contents decreased. Mineral contents increased from 46.11 - 80.21, 60.25 - 73.83, 80.33 - 99.42, 118.10 - 794.38, 1.63 - 6.32 and $0.49-1.48 \mathrm{mg} / 100 \mathrm{~g}$ for calcium, magnesium, phosphorous, potassium, iron and zinc, respectively. Potassium was the most abundant mineral in the samples. Also, retinol (11.63-16.26 $\mathrm{mg} / \mathbf{1 0 0 g})$, vitamin $B_{1}(0.10-0.21 \mathrm{mg} / 100 \mathrm{~g})$, vitamin $B_{2}(10.37-14.79$ $\mathrm{mg} / \mathbf{1 0 0 g})$, vitamin $B_{3}(9.21-9.91 \mathrm{mg} / 100 \mathrm{~g})$, vitamin $C(2.43-5.85 \mathrm{mg} / 100 \mathrm{~g})$ and vitamin $E$ $(6.43-11.25 \mathrm{mg} / 100 \mathrm{~g})$ increased significantly. Sensory analysis revealed that the Ogiri sample with $\mathbf{5 0 \%}$ soybean inclusion and the control had the best organoleptic properties. Therefore, soybean substitution of up to $50 \%$ gave a better acceptable Ogiri with improved nutrient contents.
\end{abstract}

Keywords: "ogiri", castor oil bean, soybean.

Corresponding authors email: nncntokwu@yahoo.com, +234 (0) 52425775.

\section{Introduction}

Condiments constitute an essential part of the human diet in various cultures from different parts of the world. They are mostly of two types : fermented and non-fermented food condiments. They are particularly produced from leguminous plants and oilseeds. However, in Asian continent, particularly in places like Japan, Thailand, Vietnam, Indonesia, Malaysia as well as in Northern Europe like France, fermented condiments are made from fish sauce (Okafor, 2007). Common fermented Nigerian condiments include Ogiri from castor oil bean (Ricinus communis) or melon seed (Citrullus vulgaris), 'iru' or 'daddawa' from
African locust bean (Parkia biglobosa), 'okpei' from mesquite seed (Prosopis africana) and 'ugba' from African oil bean (Pentaclethra macrophylla). Ogiri is mostly used in soup preparation to impact unique aroma and taste. It is prepared by subjecting castor oil beans to a traditional method of uncontrolled solid-state fermentation. Fermentation has been reported to increase variety in the diet, improve nutritional value, and reduce anti-nutritional compounds (Achi, 2005). Microorganisms of the genus Bacillus and Staphylococcus have been reported to be involved in the fermentation process of 'ogiri', 'ugba', 'ogiri-igbo', 'dawadawa' and 'iru' (Ezekiel et al., 2015). 
Castor oil bean seed is obtained from castor bean plant (Ricinus communis) which belongs to the class of Euphorbiaceae and family Angiosperm. The castor oil plant is indigenous to the South-eastern Mediterranean region and parts of east Africa but it is today widespread throughout the tropical regions of the world (Ibe and Orabuike, 2009) with several varieties. It contains toxic protein, ricinine and ricinoleic acid, and therefore not consumed directly without processing like fermentation that normally removes these toxic constituents (Daeschel, 1989). Castor oil bean seeds constitute about 15 to $25 \%$ fat, $25 \%$ protein, $10-20 \%$ carbohydrates, $2.2 \%$ ash content, 5.1$6.5 \%$ moisture content (Verscht et al., 2006) and about $40-53 \%$ of oil comprising glycosides of ricinoleic, isoricinoleic, stearic and dihydroxy stearic acids (Lin and Areinas, 2007).

Soybean (Glycine max) belongs to the family of leguminosae and sub-family papillionnideae. It is an important source of high quality plant protein (Kure et al., 1998) due to the presence of about $35-45 \%$ protein (Dandago and Igwe, 2006). It is rich in lysine which is deficient in most cereals. In addition, it contains an appreciable quantity of vitamins and minerals.
It is an antioxidant, lowers cholesterol level, and prevents cancer (Wada et al., 2013), lowers cardiovascular disease, regulates menopause and combat oxidative degradation for the extension of product storability. The presence of anti-nutrients like trypsin inhibitors, tannins and phytic acid that inhibit bioavailability of desired nutrients have previously limited the utilization of soybean in food production. However, fermentation and boiling have been employed to reduce them (Enujiugha, 2009). However, the use of soybean as a raw material for "ogiri" production has been poorly investigated. The aim of this study is therefore to ascertain the acceptability and nutritional properties of "ogiri" produced from partial substitution of castor oil bean with soybean seeds.

\section{Materials and Methods}

Sample acquisition

The castor oil bean (Plate 1) and soybean seeds (Plates 2) used in this research were purchased without authentication from Nsukka market, in Enugu State, Nigeria.

Table 1: Sample codes and formulation ratios for "ogiri" production.

\begin{tabular}{ccc}
\hline Sample codes & CBS (\%) & SBS (\%) \\
\hline CBS100: SBS0 & 100 & 0 \\
CBS90: SBS10 & 90 & 10 \\
CBS95: SBS5 & 95 & 5 \\
CBS50: SBS50 & 50 & 50 \\
\hline \multicolumn{2}{c}{ CBS = Castor oil bean seed. SBS = Soybean seed. }
\end{tabular}

Preparation of "ogiri" samples from castor oil bean seeds.

The method described by Ibe and Orabuike (2009) was used in the preparation of all the "ogiri" samples as shown in Figure 1.The seed pods are decorticated to release the seeds for dehulling. Dehulled castor oil bean seeds $(1 \mathrm{~kg})$ were boiled for 2 hours, strained and boiled again for 6 hours. The seeds were pounded in a clean mortar with pestle into paste, wrapped into smaller sizes with banana leaves and allowed to ferment for 5 days at room temperature $\left(25^{\circ} \mathrm{C}\right)$. The wraps were placed over the cooking pot heat source in the kitchen for 48 hours after which maximum fermentation and flavour development must have been achieved. The wraps were used for the analysis. 


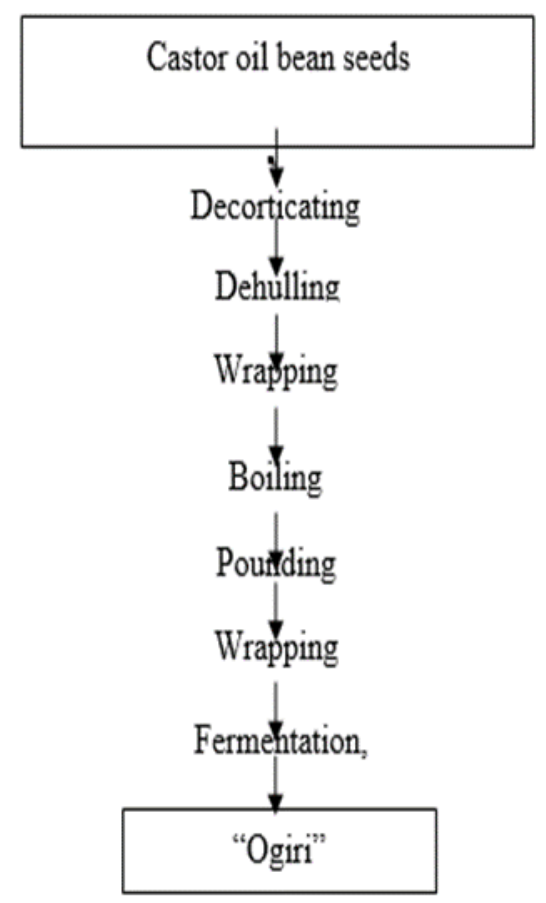

Figure 1: Flow chart for the production of "ogiri" from castor oil bean seeds.

Preparation of "ogiri" samples from soybean substituted castor oil bean seeds

Same method was used here, but castor oil bean seeds were partially substituted with soybean seeds. Castor oil bean seeds were first decorticated and dehulled to obtain the dehulled white seeds. Soybean seeds were steeped in water for 12 hours at room temperature $\left(25^{\circ} \mathrm{C}\right)$, boiled for twenty minutes (20 min) to soften the cotyledons and facilitate dehulling, hand-dehulled and the hulls were removed by water floatation to obtain the cotyledons. Dehulled castor oil bean seeds and soybean cotyledons were weighed and blended (Table 1). Each blend was wrapped and boiled separately and pounded together thereafter. The paste obtained was wrapped into smaller sizes with banana leaves and allowed to ferment for 5 days at room temperature $\left(25^{\circ} \mathrm{C}\right)$. The fermented wraps were placed over a heat source (a cooking pot in the kitchen) for 48 hours to achieve maximum fermentation and flavour development (Figure 2). The fermented wraps were used for analysis. 


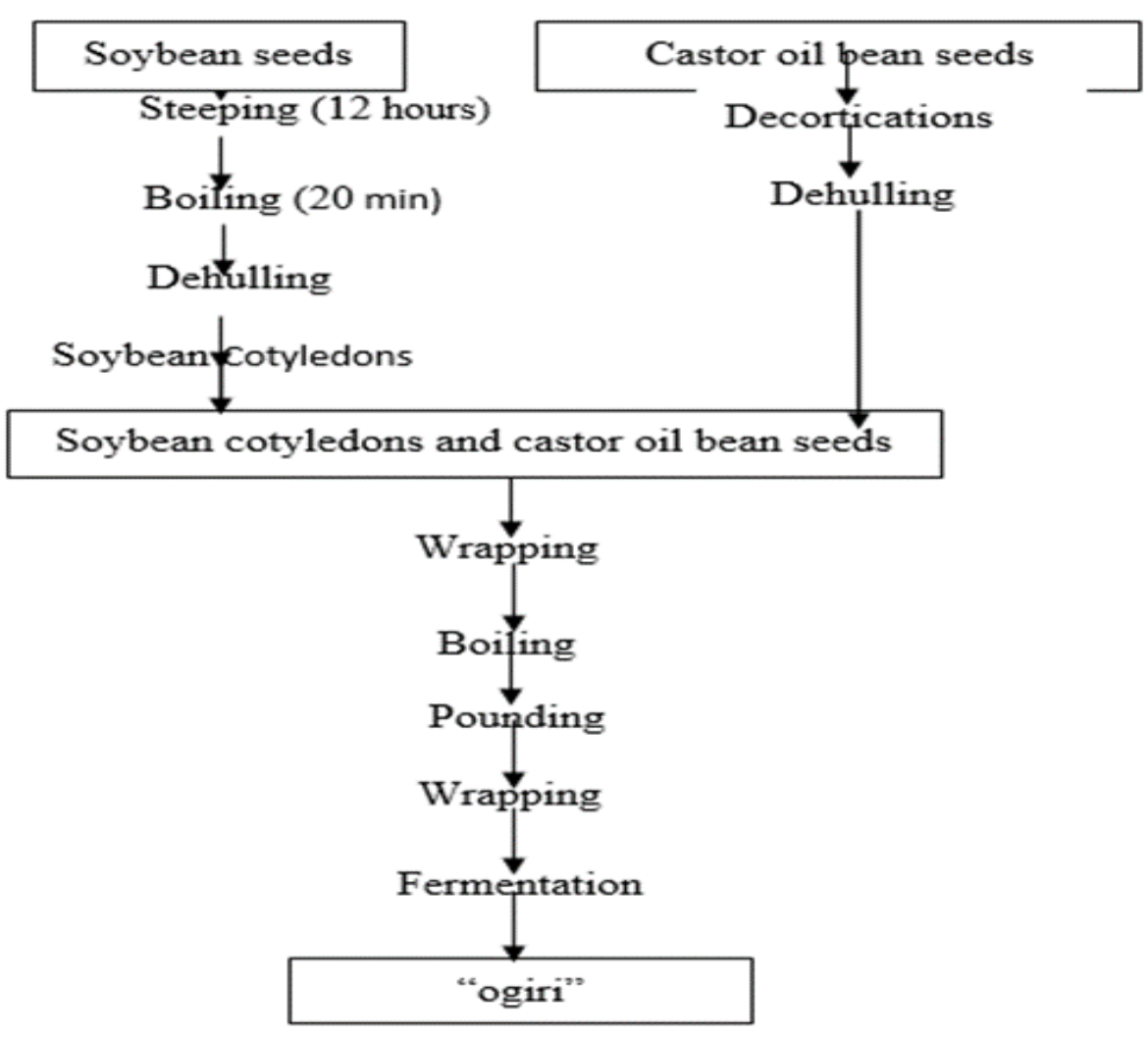

Figure 2: Flow chart for the production of "ogiri" from soybean substituted castor oil bean seeds.

\section{Proximate analysis}

The method described by AOAC (2010) was used in evaluating the moisture, crude fibre, protein, fat, and ash content, while the carbohydrate content was determined by difference.

\section{Minerals analysis}

The method described by Carpenter and Hendricks (2003) was used in determining the calcium, magnesium, potassium, sodium and phosphor us contents of the "ogiri" samples.

\section{Vitamins analysis}

Retinol, vitamin $\mathrm{B}_{1}$, vitamin $\mathrm{B} 2$, vitamin $\mathrm{B} 3$, and ascorbic acid were determined by the method described by Rutkowski (2010).

\section{Dietary energy content}

This was calculated with the Atwater factor using the energy substrates (Mullan; 2006).

\section{Sensory evaluation}

Sensory evaluation was carried out according to the method described by Iwe (2010) on each sample using 20 semi-trained panellists. Panellists were selected randomly among the students within the University community, mainly those who are used to eating "ogiri". Attributes evaluated were appearance, aroma, texture, and overall acceptability of the "ogiri" samples. They were instructed on how to taste and score the samples according to a 9- point Hedonic scale. The samples were presented separately, coded to each panellist in identical plates along with a bottle of water to rinse their mouths after testing each sample. The 9point Hedonic scale includes: $1=$ disliked extremely, 2 = dislike very much, 3 = dislike moderately, $4=$ dislike slightly, $5=$ neither like nor dislike, 6 = like slightly, $7=$ like moderately, $8=$ like very much, $9=$ like extremely. 


\section{Statistical analysis}

The data obtained from all the analyses were subjected to analysis of variance (ANOVA) of a completely Randomized design (CRD) using the SPSS version 2.0. Treatment means were separated using Duncan Multiple range test at $95 \%$ confidence level $(p<0.05)$.

\section{Results and Discussion}

\section{Proximate composition}

The results are presented in Table 2.

\section{Moisture content (MC)}

The MC of the substituted "ogiri" samples increased (17.63-19.62\%) with increasing soybean substitution levels with the CBS50:SBS50 sample having the highest value while SBS100:SBS0 (control) had the least $(16.84 \%)$. The significant $(p<0.05)$ variations between the "ogiri" samples could be attributed to soybean steeping which reflects a significant $(p<0.05) \quad M C$ variation at low soybean substitution level of $5 \%$. The MC values obtained were lower than 43.53 to $50.84 \%$ as reported by Ukaegbu (2016) and 27.00 to $31.00 \%$ by Ishiwu and Tope (2015). These discrepancies may be attributed to preparatory methods used, soybean steeping, and extent of fermentation. As the relatively high MC of the "ogiri" may likely soften the paste with enhanced freshness, quickens dissolution in soups, boosts taste and acceptability, blended samples may be better preferred to control. Blended samples may also be more shelf stable than control.

\section{Crude protein}

The crude protein content of the samples increased linearly with increase in soybean inclusion levels. Soybean substitution at $5 \%$, $10 \%$ and $50 \%$ resulted in respective higher protein content increase of $21.74 \%, 22.41 \%$ and $31.68 \%$ than the control (17.33\%). Significantly $(p<0.05)$ higher protein content of all the blended samples $(21.74-31.68 \%)$ than control $(17.35 \%)$ could be traced to higher protein content of soybean than castor oil bean. This is evident in the significant $(p<0.05)$ protein contribution by as low as $5 \%$ soybean substitution. Iwe (2003) reported that soybean contains a reasonable amount of protein which ranks highest among all the food crops. Ishiwu and Tope (2015) also reported that crude protein content increases during the fermentation process. Therefore, increased protein content of the samples could be related to the fermentation process as a result of the activities of predominant proteolytic microorganisms that hydrolyse the protein to free amino acids (Enujiugha, 2009). High protein content of the product is noteworthy since it could contribute to dietary protein in addition to its flavouring roles. Protein helps to build and maintain healthy muscle mass, while also supporting tendon, ligaments and other body tissue. It also helps to prevent spikes in blood glucose which is especially important for preventing type 2 diabetes, balancing energy levels, while keeping appetite and mood in check (Voet et al., 2008).

\section{Crude fibre}

There was a significant $(p<0.05)$ increase in the crude fibre content of the blended samples from 1.02 in sample CBS95: SBS5 to $1.71 \%$ in CBS50:SBS50, more than the control $(0.47 \%)$. Similar to crude protein content, the crude fibre content increased with increase in soybean substitution; probably, soybean crude fibre content is higher than that of castor oil bean. Fibre has been reported to offer a variety of health benefits and is essential in reducing the risk of diseases such as diabetes, obesity, cardiovascular disease and diverticulitis. It lowers the concentration of low density lipoprotein cholesterol in the blood, possibly by binding with bile acids (Ishiwu and Tope, 2015). The results obtained in this study implied that the crude fibre content of "ogiri" can be increased with the addition of soybean (as from $5 \%$ ) with the intent of improving the beneficial effect of fibre. The results were at variance with that obtained by Ukaegbu (2016) who reported fibre range of 2.59 to $7.50 \%$.

\section{Fat content}

The fat contents of the blended samples increased linearly (15.37 to 20.23\%) with increasing levels of soybean substitution $(5,19$ and $50 \%$ ) more than the control $(13.76 \%)$. Increase in fat content could be due to the fact that soybean has higher oil content (Iwe, 2003) than castor oil bean. The improved fat content of the "ogiri" samples is of nutritional significance considering its high calorific value and source of fat soluble vitamins. Besides, the fat will prevent the "ogiri" from sticking to the wrapping leaves, boost the flavour and extend 
the shelf life by reducing the rate of moisture loss. The blended samples could possibly serve as a source of essential fatty acids.

\section{Ash content}

The ash contents of the blended samples decreased (3.63 to $3.21 \%$ ) significantly $(p>0.05)$ with increase in the quantity of soybean in the blends. This may mean that castor oil bean seed contained more minerals than soybean which inclusion at 5, 10 and $50 \%$ levels used in this study reduced the mineral contents significantly $(p<0.05)$ as reflected in the decreasing ash content. At higher substitution level of soybean (CBS50:SBS50), the ash content was $3.21 \%$ while at the lowest substitution of CBS95:SBS5 the ash content was highest (3.63\%). Results obtained in this study are higher than 2.98 to $3.47 \%$ reported by Ishiwu and Tope (2015) probably due to blending, processing technique and the variety of castor oil bean used. Ash content represents total minerals content in foods and thus, serves as a viable tool for nutritional evaluation of minerals (Lienel, 2002).

\section{Carbohydrate content}

The carbohydrate content of the "ogiri" samples was found to decrease significantly $(p<0.05)$ from $48.13 \%$ in the control to $23.55 \%$ in CBS50:SBS50 with increasing level of soybean substitution. This may mean that there is lower carbohydrate content in soybean than castor oil bean seeds. Also sprouting may have contributed as well. These results are in agreement with those obtained by Sanful and Darko (2010) and Ishiwu and Tope (2015). They established that complementation with legumes such as soybean at different levels led to a decrease in carbohydrate content. Mineral composition

The results are as shown in Table 3.

\section{Calcium content}

There was a significant $(p<0.05)$ increase in the level of calcium from $62.31 \mathrm{mg} /{ }^{\circ} 00 \mathrm{~g}$ (5\% substitution) to $80.21 \mathrm{mg} / 100 \mathrm{~g}(50 \%$ substitution) among all the blended samples, more than the control $(46.11 \mathrm{mg} / 100 \mathrm{~g})$, with increasing soybean substitution. This may signify that soybean contained higher calcium than castor oil bean since as low as $5 \%$ soybean substitution could increase the calcium content significantly $\quad(p<0.05)$ from 46.11 to
$63.13 \mathrm{mg} / 100 \mathrm{~g}$. The calcium content recorded in this study was lower than that reported by Ukaegbu (2016) probably due to the variety of castor oil used and the processing technique adopted. Considering the calcium recommended daily intake (RDI) of 800-1200 $\mathrm{mg}$ /day for adults (WhereinCity, 2009), the entire "ogiri" samples were not good calcium sources. Calcium is important in the body as it helps in the building and maintenance of strong bones and teeth. It is vital for nerve transmission, muscle function, blood clotting and aids conversion of food into energy (Fallon and Enig, 2007; WhereinCity, 2009).

\section{Sodium}

For sodium content, a significant $(p<0.05)$ increase was recorded in the "ogiri" sample of $5 \%$ soybean substitution level (200.02 $\mathrm{mg} / 100 \mathrm{~g}), 10 \%(200.36 \mathrm{mg} / 100 \mathrm{~g})$ and $50 \%$ (362.42 $\mathrm{mg} / 100 \mathrm{~g}$ ) compared to the control sample (147.22 $\mathrm{mg} / 100 \mathrm{~g})$. Considering the adult RDI of $2400 \mathrm{mg} / \mathrm{d}$ (LENNTECH, 2018) for sodium, all the blended "ogiri" samples were good sodium sources, better than the control. Thus, increasing soybean substitution levels would possibly provide more sodium which has a variety of functions such as improving the functioning of the nervous system, muscular contraction and the nerves sending signals . Sodium also helps to maintain fluid balance in the body (Flack, 2018).

\section{Magnesium}

The magnesium content of the samples increased significantly $(p<0.05)$ with increasing soybean substitution levels from 67.32 (5\% substitution) to $73.83 \mathrm{mg} / 100 \mathrm{~g} \quad(50 \%$ substitution) higher than the control ( 60.25 $\mathrm{mg} / 100 \mathrm{~g}$ ). Soybean magnesium content may have been responsible for the linear increase. All samples were good magnesium sources better than the control considering the RDI of 310 to $420 \mathrm{mg} /$ day (Wyn, 2004). This increasing effect is beneficial since magnesium is a cofactor in more than 300 enzyme systems that regulate diverse biochemical reactions in the body, including protein synthesis, muscle and nerve function, blood glucose control, and blood pressure regulation (Aydin et al., 2010). It is required for energy production, oxidative phosphorylation and glycolysis. Magnesium is also needed for healthy bones, blood vessels, and essential in nerve and muscle activities (Soetan et al., 2010). 
Okwunodulu et al./ Nig. J. Biotech. Vol. 37 Num. 2: 32-46 (Dec 2020)

Table 2: Proximate composition of "ogiri" produced from castor oil bean and soybean seeds blends (\%).

\begin{tabular}{lllllll} 
Samples & Moisture & Crude Protein & Crude Fibre & Fat & Ash & Carbohydrate \\
\hline CBS100: SBS0 & $16.84^{\mathrm{d}} \pm 0.03$ & $17.33^{\mathrm{d}} \pm 0.01$ & $0.47^{\mathrm{d}} \pm 0.01$ & $13.76^{\mathrm{d}} \pm 0.01$ & $3.48^{\mathrm{c}} \pm 0.01$ & $48.13^{\mathrm{a}} \pm 0.00$ \\
CBS95: SBS5 & $17.62^{\mathrm{c}} \pm 0.02$ & $21.74^{\mathrm{c}} \pm 0.01$ & $1.02^{\mathrm{c}} \pm 0.01$ & $15.37^{\mathrm{c}} \pm 0.01$ & $3.63^{\mathrm{a}} \pm 0.01$ & $40.02^{\mathrm{b}} \pm 0.01$ \\
CBS90: SBS10 & $18.23^{\mathrm{b}} \pm 0.01$ & $22.41^{\mathrm{b}} \pm 0.01$ & $1.21^{\mathrm{b}} \pm 0.01$ & $16.01^{\mathrm{b}} \pm 0.01$ & $3.52^{\mathrm{b}} \pm 0.01$ & $39.26^{\mathrm{c}} \pm 0.01$ \\
CBS50: SBS50 & $19.62^{\mathrm{a}} \pm 0.03$ & $31.68^{\mathrm{a}} \pm 0.01$ & $1.71^{\mathrm{a}} \pm 0.01$ & $20.23^{\mathrm{a}} \pm 0.01$ & $3.21^{\mathrm{d}} \pm 0.01$ & $23.55^{\mathrm{d}} \pm 0.00$ \\
\hline
\end{tabular}

Values are means of triplicate determinations \pm standard deviation. Mean values in the same column with different superscript (a-d) are significantly different $(p<0.05)$ while those with the same superscript within the same column are not significantly different $(P>0.05)$. CBS100 is control sample with $100 \%$ castor oil bean seeds, CBS95-SBS5 is sample with $95 \%$ castor oil bean seeds and $5 \%$ soybeans seed blend, CBS90-SBS10 is sample with $90 \%$ castor oil bean seeds and $10 \%$ soybeans seed blend and CBS50-SBS50 is sample with 50\% castor oil bean seeds and $50 \%$ soybean seeds blend. 


\section{Phosphorous}

The phosphor us values obtained from the blended samples in this study increased (84.31 to $99.42 \mathrm{mg} / 100 \mathrm{~g})$ significantly $(\mathrm{p}<0.05)$ more than the control $(80.33 \mathrm{mg} / 100 \mathrm{~g})$ with increase in soybean substitution levels. Soybean may have been the major source and may have contained more phosphor us than castor oil bean. Considering the adult phosphor us RDI of $700 \mathrm{mg} / \mathrm{d}$ (Healthline, 2018), substituted samples were better sources than the control. Phosphorus works in synergy with calcium to build strong bones and teeth. These two minerals combine to form calcium-phosphate, the predominant mineral in the bones (Ebeledike et al., 2010).

\section{Potassium}

Potassium is the most abundant mineral present in the entire "ogiri" samples (118.10 to $794.38 \mathrm{mg} / 100 \mathrm{~g}$ ) with CBS50: SBS50 having the lowest value, lower than that of the control sample $(641.02 \mathrm{mg} / 100 \mathrm{~g})$, while CBS95: SBS5 had the highest value $(794.38 \mathrm{mg} / 100 \mathrm{~g})$. The results obtained in this study showed higher potassium content at low levels of soybean substitution not exceeding 10\%. Potassium RDI of $3500 \mathrm{mg} / \mathrm{d}$ (LENNTECH, 2018) implied that all the samples were poor sources. Potassium is a very important mineral for proper functioning of cells, tissues, and organs in the body. Potassium is also an electrolyte, a substance that conducts electricity in the body, along with sodium, calcium and magnesium (Flack, 2018). It plays a key role in skeletal and smooth muscle contraction, therefore important for normal digestive and muscular function (OrganicFact, 2018).

\section{Iron}

Though second to the least abundant minerals, iron content increased with significant $(p<0.05)$ variations from 1.63 to $6.32 \mathrm{mg} / 100 \mathrm{~g}$ as soybean substitution levels increased. The increase could stem majorly from soybean which may have higher iron content than castor oil bean. This is substantiated by the least iron value of the control $(1.63 \mathrm{mg} / 100 \mathrm{~g})$ and highest
(6.32 mg/100g) in sample CBS50:SBS50. With iron RDI of 10 to $18 \mathrm{mg} / \mathrm{d}$ (ODS, 2007), the entire samples were good sources. Soybean substitution in 'ogiri' production is therefore an iron improvement which helps the red blood cells to transport oxygen to all parts of the body. Iron also plays an important role in specific processes within the cell that produce energy for our body (Fallon and Enig, 2007).

\section{Zinc}

The zinc content of the entire samples (which ranged from 0.49 to $1.48 \mathrm{mg} / 100 \mathrm{~g}$ ) was the least mineral content of "ogiri". Increasing the level of soybean substitution from $5 \%$ to $50 \%$ increased the zinc $(0.61$ to $1.48 \mathrm{mg} / 100 \mathrm{~g})$ contents. With zinc RDI of $15 \mathrm{mg} / \mathrm{d}$ (LENNTECH, 2018), the entire samples were poor sources except $50: 50 \%$ substituted sample which is a good source. Zinc is needed for the body's defensive (immune) system to work properly. It plays a role in cell division, cell growth, wound healing and breakdown of carbohydrates (Singh et al., 2011).

\section{Vitamins composition}

The results are presented in Table 4.

\section{Retinol}

Retinol, a precursor of vitamin $A$, is the most abundant vitamin (11.63 to $16.26 \mathrm{mg} / 100 \mathrm{~g}$ ) in the "ogiri" may be because castor oil bean and soybean seeds are oil seeds and retinol is fatsoluble. Retinol content of the blended samples increased with significant $(p<0.05)$ variations from 13.01 (CBS95: SBS5) to $16.26 \mathrm{mg} / 100 \mathrm{~g}$ (CBS50:SBS50) with increasing level of soybean substitution. Soybean probably contains a more reasonable amount of vitamin $A$ (Omafuvbe et al., 2003) than castor oil bean. The substituted samples are better sources of retinol than the control considering $700 \mu \mathrm{g} / \mathrm{d}$ retinol RDI (Olson, 1987). Retinol, a powerful antioxidant, plays a critical role in maintaining healthy vision, neurological function, healthy skin and supports immune function. It is involved in reducing inflammation through fighting free radical damage (Onyeka, 2008). 
Okwunodulu et al./ Nig. J. Biotech. Vol. 37 Num. 2: 32-46 (Dec 2020)

Table 3: Mineral composition of "ogiri" produced from castor oil bean seed and soybean seeds $(\mathrm{mg} / 100 \mathrm{~g})$.

\begin{tabular}{|c|c|c|c|c|c|c|c|}
\hline Sample & Calcium & Sodium & Magnesium & Phosphorus & Potassium & Iron & Zinc \\
\hline CBS100: SBS0 & $46.11^{d} \pm 0.01$ & $147.22^{\mathrm{d}} \pm 0.01$ & $60.25^{d} \pm 0.01$ & $80.33^{d} \pm 0.01$ & $641.02^{c} \pm 0.01$ & $1.63^{\mathrm{d}} \pm 0.01$ & $0.49^{d} \pm 0.01$ \\
\hline CBS95: SBS5 & $62.31^{\mathrm{c}} \pm 0.01$ & $200.02^{c} \pm 0.01$ & $67.32^{c} \pm 0.01$ & $84.31^{c} \pm 0.01$ & $794.38^{a} \pm 0.33$ & $1.90^{c} \pm 0.00$ & $0.61^{c} \pm 0.01$ \\
\hline CBS90: SBS10 & $63.13^{b} \pm 0.01$ & $200.36^{c} \pm 0.01$ & $68.23^{b} \pm 0.01$ & $86.83^{b} \pm 0.02$ & $782.12^{b} \pm 0.01$ & $1.94^{b} \pm 0.01$ & $0.65^{\mathrm{b}} \pm 0.01$ \\
\hline CBS50: SBS50 & $80.21^{a} \pm 0.01$ & $362.42^{\mathrm{a}} \pm 0.01$ & $73.83^{a} \pm 0.02$ & $99.42^{a} \pm 0.01$ & $118.10^{d} \pm 0.03$ & $6.32^{a} \pm 0.01$ & $1.48^{\mathrm{a}} \pm 0.01$ \\
\hline
\end{tabular}

Values are means of triplicate determinations \pm standard deviation. Mean values in the same column with different superscript (a-d) are significantly different $(p<0.05)$ while those with the same superscript within the same column are not significantly different $(P>0.05)$. CBS100 is control sample with $100 \%$ castor oil bean seeds, CBS95-SBS5 is sample with 95\% castor oil bean seeds and 5\% soybeans seed blend, CBS90-SBS10 is sample with $90 \%$ castor oil bean seeds and $10 \%$ soybeans seed blend and CBS50-SBS50 is sample with $50 \%$ castor oil bean seeds and $50 \%$ soybean seeds blend. 


\section{Vitamin B-complex}

Vitamin $B_{1}$ complex increased from 0.17 to $0.21 \mathrm{mg} / 100 \mathrm{~g}, B_{2}$ from 10.37 to $14.79 \mathrm{mg} / 100 \mathrm{~g}$ and $B_{3}$ from 9.21 to $9.91 \mathrm{mg} / 100 \mathrm{~g}$. The increase was significant $(p<0.05)$ in all the substituted samples with increase in soybean substitution levels with the sample CDS50:SBS50 having the highest values. Only $B_{1}$ at $5 \%$ and $10 \%$ substitution levels had lower value than the control sample $(0.17 \mathrm{mg} / 100 \mathrm{~g})$ but higher $(0.21 \mathrm{mg} / 100 \mathrm{~g})$ at $50 \%$ substitution level. Higher levels of B-complex vitamins in CBS50: SBS50 could be attributed to the increase in soybean inclusion which is a good source of Bcomplex vitamin (Iwe, 2003). However, the soybean substitution levels $5 \%, 10 \%$ and $50 \%$ used improved that the samples are good vitamins sources considering the respective RDIs of $1.4,1.6$ and $18 \mathrm{mg} / \mathrm{d}$ (LENNTECH, 2018) for $\mathrm{B}^{1}, \mathrm{~B}^{2}$ and $\mathrm{B}^{3}$, respectively. Vitamin $B_{1}$ is part of the eight nutrients that make up the B-complex family and plays an important role among others in red blood cell formation, cognitive function, sugar oxidation, digestion, improves appetite and serves as an anti-stress (ProHealth, 2018).

\section{Vitamin C}

The vitamin $C$ content of the blended samples increased significantly $(p<0.05)$ from 3.62 (CBS95: SBS5) to $5.85 \mathrm{mg} / 100 \mathrm{~g}$ (CBS50:SBS50) more than the control (3.41 $\mathrm{mg} / 100 \mathrm{~g}$ ) with increasing soybean substitution levels. Notably, the inclusion of soybean which had been reported to contain $2.92 \mathrm{mg} / 100 \mathrm{~g}$ vitamin C (Enujiugha, 2009) may have been the major source. Also, soybean vitamin $\mathrm{C}$ may be higher than that of castor oil bean. Vitamin $\mathrm{C}$ contents of the substituted samples are good sources more than the control considering the RDI of $45 \mathrm{mg} / \mathrm{d}$ (MedicineNet, 2011). Vitamin $C$ helps to purify the blood as an antioxidant (Cohen et al., 2000), maintains healthy immune systems, fights infections and is required for the synthesis of collagens. It also maintains healthy muscle, vascular tissue, tendons, ligaments, teeth, bones, gum, cartilage, joints, lining, skin and blood vessels (MedicineNet, 2011).

\section{Vitamin $E$}

The Vitamin $E$ content of the blended samples increased significantly $(p<0.05)$ from $7.52 \mathrm{mg} / 100 \mathrm{~g}$ to $11.25 \mathrm{mg} / 100 \mathrm{ml}$ which is lower than the content observed in the control $(6.43 \mathrm{mg} / 100 \mathrm{~g})$ with increasing soybean levels of the substitution. Due to the improvement, the substituted samples are better sources of vitamin $\mathrm{E}$ than the control when compared to the RDI of $20 \mathrm{mg} / \mathrm{d}$ (NIH, 2018). Vitamin $\mathrm{E}$ is a strong antioxidant that potentially prevents damages caused by free radicals that can modify cell components like proteins, DNA and lipids. Vitamin $\mathrm{E}$ had been reported to prevent oxidation of low-density lipoprotein cholesterol in vascular cells (Skyrme et al., 2000). Thus, vitamin E may play the role of preventing atherosclerotic cardiovascular diseases and cancer . It is also critical in maintaining cellular functionality in general, inhibits cell proliferation and enhances immune function (Meydani et al., 2005).

\section{Calorific value of the "ogiri" samples}

The calorific values of the blended "ogiri" samples as presented in Table 5 increased significantly $(p<0.05)$ with increase in soybean inclusion levels thereby implicating soybean as a better energy source than castor oil bean. The CBS50: SBS50 sample had the highest energy value $(378.98 \mathrm{Kcal})$ while CBS95:SBS5 had the least $(237.32 \mathrm{Kcal})$ which is lower than the control $(373.32 \mathrm{Kcal})$. Dietary energy is a non-nutritive component of foods responsible for metabolic processes, physiological functions, muscular activity, heat production, growth, transport of substances round the body, synthesis of enzymes and hormones in the body (NHMRC, 2016). 
Okwunodulu et al./ Nig. J. Biotech. Vol. 37 Num. 2: 32-46 (Dec 2020)

Table 4: Vitamin content of "ogiri" produced from Castor oil bean seed and Soybean seed blends (mg/100 g).

\begin{tabular}{|c|c|c|c|c|c|c|}
\hline Samples & Retinol & $\begin{array}{c}\text { Vitamin } \\
B_{1}\end{array}$ & $\begin{array}{c}\text { Vitamin } \\
\mathrm{B}_{2}\end{array}$ & $\begin{array}{c}\text { Vitamin } \\
\mathrm{B}_{3}\end{array}$ & $\begin{array}{c}\text { Vitamin } \\
\text { C }\end{array}$ & $\underset{\mathrm{E}}{\text { Vitamin }}$ \\
\hline CBS100:SBS0 & $11.63^{d} \pm 0.01$ & $0.17^{b} \pm 0.01$ & $10.37^{d} \pm 0.01$ & $9.21^{\mathrm{d}} \pm 0.01$ & $2.43^{\mathrm{d}} \pm 0.01$ & $6.43^{\mathrm{d}} \pm 0.02$ \\
\hline CBS95: SBS5 & $13.01^{\mathrm{c}} \pm 0.01$ & $0.10^{d} \pm 0.00$ & $11.63^{c} \pm 0.01$ & $9.28^{c} \pm 0.01$ & $3.62^{c} \pm 0.01$ & $7.52^{c} \pm 0.01$ \\
\hline CBS90: SBS10 & $13.09^{b} \pm 0.01$ & $0.14^{c} \pm 0.01$ & $11.81^{\mathrm{b}} \pm 0.01$ & $9.49^{b} \pm 0.01$ & $3.79^{b} \pm 0.01$ & $8.06^{\mathrm{b}} \pm 0.01$ \\
\hline CBS50: SBS50 & $16.26^{\mathrm{a}} \pm 0.01$ & $0.21^{\mathrm{a}} \pm 0.00$ & $14.79^{\mathrm{a}} \pm 0.01$ & $9.91^{\mathrm{a}} \pm 0.01$ & $5.85^{\mathrm{a}} \pm 0.01$ & $11.25^{\mathrm{a}} \pm 0.01$ \\
\hline
\end{tabular}

Values are means of triplicate determinations \pm standard deviation. Mean values in the same column with different superscript (a-d) are significantly different $(p<0.05)$ while those with the same superscript within the same column are not significantly different $(P>0.05) . \pm$ 
Table 5: Calculated dietary energy values of "ogiri" samples by Atwater factor

\begin{tabular}{lclllll}
\hline Sample & Protein (\%) & Fiber (\%) & Fat (\%) & $\begin{array}{l}\text { Carbohydrate } \\
\mathbf{( \% )}\end{array}$ & $\begin{array}{c}\text { Energy values } \\
\mathbf{K j} / \mathbf{g}\end{array}$ & $\begin{array}{c}\text { Energy values } \\
\mathbf{K c a l} / \mathbf{g}\end{array}$ \\
\hline CBS100:SBS0 & 17.33 & 0.47 & 13.76 & 48.13 & $1569.48^{\mathrm{c}} \pm 0.11$ & $373.32^{\mathrm{c}} \pm 0.03$ \\
CBS95:SBS5 & 21.74 & 1.02 & 15.37 & 40.02 & $1559.73^{\mathrm{d}} \pm 0.04$ & $237.32^{\mathrm{d}} \pm 0.03$ \\
CBS90:SBS10 & 22.41 & 1.21 & 16.01 & 39.06 & $1582.17^{\mathrm{b}} \pm 0.10$ & $376.99^{\mathrm{b}} \pm 0.13$ \\
CBS50:SBS50 & 31.68 & 1.71 & 20.23 & 23.55 & $1623.55^{\mathrm{a}} \pm 0,07$ & $387.98^{\mathrm{a}} \pm 0.11$ \\
\hline
\end{tabular}

Values are means of triplicate determinations \pm standard deviation. Energy values in same column with same superscript have no significant difference $(P<0.05)$ while those with different superscript have significant $(P \geq 0.05)$. CBS100:SBS0 is $100 \%$ castor oil bean seed "ogiri",CBS95:SBS5 is "ogiri" made from $95 \%$ castor oil bean seed and 5\% soybean seed blends, CBS90:SBS10 is "ogiri" made from 90\% castor oil bean seed and 10\% soybean seed blend and CBS50:SBS50 is "ogiri "made from $50 \%$ castor oil bean seed and $50 \%$ soybean seed blend.

Sensory characteristics

The results for sensory characteristics of the condiments are presented in Table 6.

The appearance scores of the blended "ogiri" samples increased significantly $(p<0.05)$ from 4.70 to 7.15 with increase in soybean substitution levels. Samples CBS95: SBS5 (4.70) and CBS90: SBS10 (4.25) with respective soybean substitution levels of 5 and $10 \%$ had lower scores each than the control sample (6.20), which suggested that the improvement in the appearance of the blended samples was from the $10 \%$ soybean inclusion. However, the appearance of the "ogiri" sample with $50 \%$ soybean (7.15) was the most preferred by the panellists.

The aroma scores of the blended samples increased $(4.60-6.65)$ significantly $(p<0.05)$ with increasing soybean substitution level, with the sample CBS50:SBS50 having the highest value (6.65). This increase could be attributed to the significant $(p<0.05)$ protein content (Table 2) of the sample, which is the major aroma source in "ogiri". Protein is the major substrate responsible for the release of aromatic substances peculiar to "ogiri" by the fermenting organisms (Ouoba et al., 2005). Similar to the appearance scores, the scores for $5 \%$ (4.60) and $10 \%$ (4.15) soybean substitution were lower than the control sample (5.60).

The texture scores of the blended samples increased $(5.30-6.40)$ with significant $(p<0.05)$ variations as soybean substitution levels increased. Only the texture score of the sample CBS50:SBS50 (6.40) was higher than the control (5.85) which implies that texture improvement of the "ogiri" samples will increase as from $50 \%$ soybean substitution level.
General acceptability test revealed that the $50 \%$ soybean substitution level was preferred (6.85) better than the $100 \%$ castor oil bean. This could be traced to the increased protein content as explained before as "ogiri" is rated for its flavour. Also, increasing fat content (Table 2) is another contributing factor since it is a flavour enhancer. Furthermore, the sample CBS50: SBS50 had the highest scores in all the organoleptic properties evaluated.

\section{Conclusion}

This study revealed that with increase in soybean substitution levels, the proximate composition of the "ogiri" samples increased proportionately, except for ash and carbohydrate contents which showed decreasing values. There were increasing mineral content at soybean substitution levels not exceeding $10 \%$, with potassium being the most abundant. Also, the entire samples were good sources of sodium, magnesium, phosphor us and iron, but were poor sources of calcium, potassium and zinc. Furthermore, all the vitamin contents of the substituted "ogiri" samples improved to become good sources with retinol being the most abundant. Energy values also improved. The "ogiri" sample with $50 \%$ soybean inclusion had the best organoleptic properties of all the samples, substantiating all the maximum nutrient contents obtained in this study at $50 \%$ soybean inclusion. This study has therefore demonstrated the production potential, nutrition, acceptability and health benefits of soybean inclusion in "ogiri" production. 
Table 6: Sensory properties of the "ogiri" produced from castor oil bean and soybean seeds blends.

\begin{tabular}{lllll} 
Samples & Appearance & Aroma & Texture & $\begin{array}{l}\text { General } \\
\text { acceptability }\end{array}$ \\
\hline CBS100:SBS0 & $6.20^{\mathrm{b}} \pm 1.85$ & $5.60^{\mathrm{b}} \pm 1.85$ & $5.85^{\mathrm{b}} \pm 2.08$ & $6.00^{\mathrm{b}} \pm 2.00$ \\
CBS95: SBS5 & $4.70^{\mathrm{c}} \pm 1.75$ & $4.60^{\mathrm{c}} \pm 1.69$ & $5.30^{\mathrm{c}} \pm 1.63$ & $5.15^{\mathrm{c}} \pm 1.81$ \\
CBS90: SBS10 & $4.25^{\mathrm{d}} \pm 2.02$ & $4.15^{\mathrm{d}} \pm 1.66$ & $4.65^{\mathrm{d}} \pm 1.79$ & $4.35^{\mathrm{d}} \pm 1.93$ \\
& & & & \\
CBS50: SBS50 & $7.15^{\mathrm{a}} \pm 1.87$ & $6.65^{\mathrm{a}} \pm 2.23$ & $6.40^{\mathrm{a}} \pm 1.43$ & $6.85^{\mathrm{a}} \pm 1.31$
\end{tabular}

Values are means of triplicate determinations \pm standard deviation. Mean values in the same column with different superscript $(a-d)$ are significantly different $(p<0.05)$ while those with the same superscript within the same column are not significantly different ( $P>0.05)$. CBS100 is control sample with $100 \%$ castor oil bean seeds, CBS95-SBS5 is sample with $95 \%$ castor oil bean seeds and $5 \%$ soybeans seed blend, CBS90-SBS10 is sample with $90 \%$ castor oil bean seeds and $10 \%$ soybeans seed blend and CBS50-SBS50 is sample with $50 \%$ castor oil bean seeds and $50 \%$ soybean seeds blend.

\section{References}

Achi, O. K. (2005). The potentials for upgrading of traditional fermented foods through biotechnology.

Afr. J. of Biot. 4:375-380.

AOAC (2010): Official Methods of Analysis. $18^{\text {th }}$ Edition, Association of Official Analytical Chemists, Washington D.C., USA.

Aydin, S., Croteau, G., Sahin, I. and Citil, C. (2010). Ghrelin, nitrite and paraoxonase/ arylesterase concentrations in cement plant worker. J. Med. Bioch. 29-2:78-83.

Carpenter, C.E., Hendricks, D.G. (2003). Mineral Analysis. In: Food Analysis $3^{\text {rd }}$ Ed. Springer LLC, New York, and N.Y. p. 198-206.

Cohen, L., Manion, L., and Monison, K (2000). Research methods in Education $5^{\text {th }}$ Ed. London: Routledge Falmer.

Daeschel, M. M. (1989). Anti-microbial substances from lactic acid bacteria for use as food preservatives Food Technol. 43: 164-167.

Dandago, M. A. and Igwe, C. E. (2006). Production and sensory evaluation of soya yoghurt.

Int. J. Food Agricultural Research 3 (1): 36- 39.

Ebeledike, E. U., Godwin, I. C., Nwokedi, O., Ndu, F. O., Festus, Okoye, B. C. and Izuchukwu, S. O. (2010). Calcium and phosphorus contents of body parts of some domestic animals used as meat source in Nigeria. Asian Pacific Journal of tropical Medicine, 395-398.

Enujiugha, V.N. (2009). Major fermentative organisms in some Nigerian soup condiments.

Pak. J. Nutr. 8:279-283.

Ezekiel, O. O., Ogunshe, A. A. O., Jegede, D. E. (2015). Controlled fermentation of cotton seeds (Gossypium hirsutum) for Owoh production using bacteria starter cultures. Nig. Fd. J. 33 (1): 54-60.

Fallon, S.and Enig, M.G.2007. Nourishing Tradition In: The Cookbook that Challenges Politically Correct Nutrition and the Diet Dictocrates.NewTrends Publishing Inc.www. Newtrendpublishing.com.

Flack, A. 2018. The Advantages and Disadvantages of Sodium for Nutrition. Sfgate.com/advantagesdisadvantages.

Healthline, (2018).Top 12 Foods that are high in Phosphorous.

http://www.healthline.com/nutrition/Foodshigh-in-phosohorous Retrieved on 05/07/18.

Ibe, U. and Orabuike J.C. (2009). Production, nutritional, sensory and storage profile of ogiri from castor oil seed. Paper presented at Danida Int. seminar, Ouagadougou, Burkina Faso. 
Ishiwu, C. N. and Tope, V. A. (2015). Effect of period of fermentation on nutrients of castor oil seed (Ricinus communis).Dir. Res. J. of Agr. Fd. Sci. 3 (10):178-183

Iwe, M.O. (2003). The Science and Technology of Soybean. Rejoint Communications Services Ltd. Enugu, Nigeria. p. 3-31.

Iwe, M.O. (2010). Handbook of Sensory Methods and Analysis. Rejoin com. Service Ltd. Enugu, Nigeria. P. 12-18

Kure, O. A., Bahago, E. J. and Daniel, E. A. (1998). Studies on the proximate composition and effect of flour particle size of acceptability of biscuits produced from blends of soybeans and plantain flours. Namoda Tech. Scope J. $3(2): 17-22$.

LENNTECH, 2018. Recommended Daily Intake of Vitamins and Minerals

.http://lenntech.com/recom. Assessed 2018

Lienel, H.H. (2002). Ash analysis, In: Introduction to Chemical Analysis of Foods. CBS publishers, New Delhi, India. p. 113-123.

Lin, J. T. and Areinas, A. (2007). Reginospecific analysis of diricinoleoylacylglycerols in castor (Ricinus communis L.) oil by electrospray ionization-mass spectrometry. J. Agric. Fd. Chem. 44(2):303-307.

MedicineNet (MN) (2011), Definition of ascorbic acid. available:

https://www.medicinenet.com/script/main/art. asp?articlekey $=12536$.

Meydani S.N., Meydani M., Blumberg J.B., Leka L.S, Siber G., Loszewski. R. (2005) Vitamin E supplementation and in vivo immune response in healthy elderly subjects: $A$

randomized controlled trial.: 277: 1380-1386

Mullan, W. M. A. (2006). Labeling determination of the energy content of food (On-line).

http://www.dairyscience.info/packing-/119labelling-determination-of-the-energy-contentof-food-html.

National Institute of Health Office of Dietary Supplement (NIH) (2018). Vitamin E-Health professional fact sheet. http://ods od n.hugov/factsheets/VitaminE-

HealthProfessional/
Nutritional Health and Medical Research Council (NHMRC) (2016). Dietary Energy. https://www.nrv.gov.au/sites/default/files/pag e pdf

Okafor, N. (2007). Modern Industrial Microbiology and Biotechnology. USA: Science Publishers; 207-211.

Olson, J. A. (1987). Recommended dietary intakes (RDI) of vitamin $A$ in humans. The American J. of Clinical Nutrition. 45(4).

Omafuvbe, B. O., Abiose, S.H. and Shonukan, O.O. (2003). Fermentation of soybean (G/ycine max) for soy-daddawa production by starter cultures of Bacillus. Fd. Micro. 19: 561-566.

Onyeka, E.U. (2008): Mineral Elements and their Importance in Food and Nutrition, $2^{\text {nd }}$ Edition,, Owerri: Charismatic Publishing.

OrganicFacts 2018. 13 Incredible Benefits of Potassium. http://www.organicfact.net/

Ouoba, L.I.I, B. Diawara, N.T. Annan, L.P., Jakoben, M. (2005). Volatile compounds of soumbala, a fermented African Locust bean (Parkia biglobosa). Fd. condi. 33-39.

ProHealth, (2018): What are health benefits of vitamin B1, thiamine? Prohealth.com/library/benefits-vitamin-b1thiamine-88002. Retrieved on 5/6 2018.

Rutkowski K.J. (2010) Spectrophotometric Method of Vitamin Quantification in Foods. Chapman and Hall, New York. P. 98-118.

Ukaeghu (2016). Chemical composition of some selected ogiri samples in Anambra State The proceedings of the $2^{\text {nd }}$ South Summit (ReFoST). Theme: Technology for nutrient diversification and Calorie Management in Beverages. Umuahia, June, $9^{\text {th }}-11^{\text {th }} 33-34$.

Sanful, R. E. and Darko, S. 2010. Utilization of soybean flour in the production of bread.

Pak. J. Nutri. 9(8): 815 - 818.

Sharma, J.L (2002). A dictionary of food and nutrition, $2^{\text {nd }}$ edition, Macmillan publisher, London. Pp: 698-830.

Singh, M. and Das, R.R.2011. Zinc for the common cold. Cochrane database syst. Rev. Feb 16, 2011.

Skyrme, S.S and Jones, R.A.P. (2000). Impaired endothelial function in insulin-dependent 
diabetes is related to LDL particle size and LDL vitamin E. J. Am. Collcardiol. 35:292-299.

Soetan, K. O., Olaiya, C. O. and Oyewole, O. E. (2010). The importance of mineral elements for humans, domestic animals and plants, Sourced from a market in Ogbomoso, Nigeria. African Journal of food science, 3, 51-55.

Verscht, J., Tomos, D. and Komor, K. (2006). Sugar concentrations along and across the Ricinus communis $L$. hypocotyls measured by single cell sampling analysis. Planta 224(6):1303-1304.
Voet, D. J., Voet, J. G. and Pratt, C. W. 2008. The principles of Biochemistry. Hoboken publication. 74-219.

Wada, K., Nakamura, K., Tamai, Y., Tsuji, M., Kawachi, T., Hori, A., Takeyama, N., Tanabashi, S., Matsushita, S., Tokimitsu, N. and Nagata, C. (2013). Soy isoflavone intake and breast cancer risk in Japan: From the Takayama study. Int. J. Cancer 133:952 - 960.

WhereinCity Medical (WM) 2009. Calcium. Wherencity Medical http://www.wherencity.com/medical/minerals/ cdcium.php. 